\title{
AN INTERPRETIVE STUDY OF THE COMMUNICATION NEEDS OF ENGLISH DEPARTMENT STUDENTS AT UNIVERSITY OF MUHAMMADIYAH MALANG
}

\author{
Dwi Poedjiastutie, Kharisma Naidi W.S, Teguh Hadi S, Aninda N.H \\ FKIP UniversitasMuhammadiyah Malang \\ Email: dwi.poedjiastutie@postgrad.curtin.edu.au
}

\begin{abstract}
At English Department (ED) UMM, students learn communication for General Purposes (GE) and the generality of the communication materials very much depend on the teachers' decisions. In other words, teachers can decide any topics and materials depending on the communication books they possessed and read. Even so, many of them by the end of their study period are still not able to speak English fluently. This research is to provide information needed for the curriculum development and classroom instruction through Needs Analysis (NA). The research questions for this study cover (1) what communication skills and competence are expected by ED UMM students? To answer the following questions, an interpretive research paradigm will be employed in the proposed research. In an interpretive research paradigm, theories are constructed from the data rather than theories preceding the data. The data in this research is the participants' goals, reasons, motives, feelings, perspectives, and assumptions and these participant perspectives will be viewed through the lens of their cultural contexts. This approach uses three-stage data collection and analysis, namely: FGD (focus-group interview) with ED students. The findings showed:There are three areas that both English Department and Faculty of Education should give more attention for the improvement of students' communication competence. The goals of speaking subject should be made clear by having the students' voices heard and employing the appropriate Needs Analysis (NA) study. The second was the speaking teacher recruitment process should be made transparent. Last but not least is the importance for English Department to understand students' expectations of how speaking subjects should be run and implemented so that they will achieve communication development.
\end{abstract}

Key words: Needs Analysis, Interpretive Study, Communication Needs

\section{RINGKASAN}

Pemilihan materi mata kuliah speaking di jurusan Bahasa Inggris sangat tergantung pada pengajar atau pengampu mata kuliah tersebut. Silabus mata kuliah speaking sering kali hanya menjadi dokumen resmi tanpa penerapan yang jelas terutama dimata kuliah tersebut. Hal ini ditenggarai membuat hasil belajar terutama kemampuan berkomunikasi mahasiswa Bahasa Inggris menjadi rendah. Penelitian ini ditujukan mencari jawaban atas permasalahan tersebut. Apakah silabus mata kuliah Bahasa inggris terutama speaking tidak diikuti oleh banyak pengajar speaking sendiri. Untuk mencari motives atau alasan mengapapengajar bertindak seperti itu pendekatan kwalitatif digunakan oleh penulis. Data dikumpulkan dengan melakukan wawancara individu kepada dosen pengampu mata kuliah speaking dan wawancara kelompok dengan mahasiswa yang menempuh mata kuliah speaking. Hasilnya adalah baik Fakultas Keguruan dan Ilmu Pendidikan dan Jurusan Pendidikan Bahasa Inggris harus Bersama-sama memperhatikan tiga hal yaitu. Meningkat kemampuan dosen untuk 
ketrampilan Analisa kebutuhan (NA), rekruitmen dosen Speaking yang sifatnya transparan tidak sekedar native speaker dan tujuan pengajaran speaking yang bergradasi antara speaking yang terendah (basic) sampai yang tertinggi (advance)

\section{INTRODUCTION}

The current status of English as an international or global language is evident by its wide use in a range of fields such as politics, diplomacy, international trade and industry, commerce, science and technology, education, the media, information technology, and popular culture (Crystal, 2003; Huda, 2000; Jenkins, 2003). English is increasingly used as a medium of instruction in schools and universities and is also taught widely as a foreign language for students intending either further study in an English speaking country or as a requirement for employment (Lauder, 2008).The international value of English as a lingua franca, has led to a commitment by the government of Indonesia to the teaching of English at all levels of education.

The relationship between English and employability is a significant one. Employability can be viewed as the ability to get a job, maintain it or get a new one (Kirubahar, Santhi, \&Subashini, 2010). In some cases, and especially so in current times in Indonesia, this will depend on the ability to speak English fluently and to effectively communicate one's ideas orally as well as having competence in reading and writing in English. Although Coleman (2010) argues that several earlier studies have failed to find convincing evidence linking English competence to the economic development of the individual or nation, other recent studies suggest that there may indeed be a positive relationship between English competence and employability. For this reason, it is not surprising that the teaching of English as a Foreign Language (EFL) is continue to occur at tertiary level in Indonesia. Many university students are now aware the relevance of having communicative competence to their future careers. This is in contradiction with Focho (2010) had claimed that English teaching in most developing country is problematic since students may fail to see its relevance to their immediate or future needs.

Nowadays English is the dominant language of communication worldwide, even among non-native speakers. Due to that English also plays a significant role in the curriculum at UMM. Located in Malang, Indonesia, UMM is the largest private Islamic University in East Java Province with a total of 18,000 students from different parts of Indonesia. The English Department UMM (ED UMM) is the most frequently selected higher education destination for senior high school graduates in East Java. Since 1999, the ED UMM has accepted approximately 250 students each year.

In 2012, a tracer study was conducted by ED UMM staff in which a questionnaire was distributed to 2000 students from the academic years 2009 to 2011. From this research, it was found that the majority of ED UMM graduates on completion of the first degree intended to be job seekers rather than pursuing higher degrees. Further, the study reported that students expected that studying English as a means of global communication would prepare and equip them with the necessary language competency required for future employment (Tracer Study, 2012). More 
than $80 \%$ indicated their intention to go into jobs as English teachers, from primary to university level, with less than $20 \%$ indicating that they would go into other professions (English Department Tracer Study, 2012).

In many workplace situations communication is needed. For example, research conducted by Ghenghesh (2013) has indicated that the engineering students felt the need of communication skills for engineering purposes. While Brunton (2009) sought needs information on Hotel employees. Chen (2006) focused more on communication needs of the bank employees.

At English Department (ED) UMM students learn communication for General Purposes (GE) and the generality of the communication materials very much depend on the teachers' decisions. In other words, teachers can decide any topics and materials depending on the communication books they possessed and read. For example, the syllabus mentions very general information on the communicative competence that students must possess and master. Even so, many of them by the end of their study period are still not able to speak English fluently.

The low and lack communication capability will definitely disadvantage students since they are going to compete for the future jobs inside or outside the country. The values of their educational investment can be useless.

To address this concern, several steps have been taken to improve ED UMM students' level of English competence including redesigning the English curriculum. However, despite the obvious need to first do so, there has been no systematic analysis of needs when attempts are made to tailor the curriculum or the classroom instruction to the particular needs of UMM teaching graduates.

This is a practice contrary to that recommended in the literature, especially with regard to implementing curriculum changes. For example,Hamp-Lyons (2001)and Finney (2002) argue that a needs analysis has a vital role in the process of designing and carrying out any language course, whether it be English for Specific Purposes (ESP) or general English courses.

In addition,I. Leki (2003) suggests English courses are more beneficial if the goals reach beyond the class as an end in itself towards the real needs of learners and other stakeholders. Moreover, it is the existing institutions' responsibility (e.g., ED UMM) to know and to anticipate the future needs of stakeholders and society (Oliver et.al, 2012). Collecting and analyzing data on needs allows teachers to describe the gap between what has been done and what is needed to be done. Thus, a needs analysis can support the development and implementation of language policies at both macro and micro levels, with far-reaching consequences.

The research problems of the current study as follows:

What are English Department communication needs from students' own perspectives?

\section{METHOD}

An interpretive research paradigm was employed in the proposed research. In an interpretive research paradigm, theories are constructed from the data rather than theories preceding the data (Erlandson, Harris, Skipper, \& Allen, 1993). The data in this research is the participants' goals, reasons, motives, feelings, perspectives, and assumptions (Fraenkel, Wallen, \& 
Hyun, 2012) and these participant perspectives will be viewed through the lens of their cultural contexts

In this study learners' perceptions of communication needs were ascertained using focus group interviews. The participant were ED UMM students enrolled in all academic year. There are 16 students from different academic years attended two Focus Group Discussions (FGD). . Each focus group was limited up to 8 students, as this has been found to be the optimum number of participants for focus group research (Fraenkel, et.al, 2012, p. 423). Different focus groups was be conducted until it emerges from the ongoing thematic analysis of responses that no more new perspectives are revealed, that is until saturation is reached.

A think-aloud process wasemployed to analyze the data obtained through the focus group interviews with studentsto find out the emergent themes and typological dimensions (Lincoln \& Guba, 1985, p. $335)$ or it is known as new categories.

\section{RESULT AND DISCUSSION}

The Focus Group Discussion (FGD) was conducted twice with different group of students and in two different schedules. Before elaborating the result, it is important to describe students who studied at ELED this university.

The students at UMM are very diverse in terms of their backgrounds home location, ethnicity, socio-economic backgrounds, and the level of their knowledge of the Islamic religion. In addition, there are also a small percentage of non-Muslim students enrolled at the university. In the coming years, it is predicted that the proportion of new students from Malang will be equal to the number of students coming from other regions in East Java. Students coming from
East Indonesia are predicted to increase significantly.

The unit responsible for English language teaching at UMM is the Department of English Language Education, also known as the English Department (ELED UMM). Graduates of ED UMM usually go into teaching careers at primary to high school levels.

\section{The Goals of Speaking Course}

Almost all students said that to be able to communicate was their first priority to master compared to the other skills. Many students agree that communication in general will help them to secure jobs. This is a bit contradictory with the expectations by the teacher. Teachers wanted the syllabuses were modified to meet students' communication skills for GE and Academic English. As a matter of fact, when they graduated from ELED, some FGD participants wanted to go for careers other than teaching such as international motivators, translation center, flight attendance, teachers in overseas higher education. Therefore, many of them said that communication was still critical.

- If you work in a translation company don't you think that writing and translation skills are more important than communication one?

- I think communication is also important to market or to promote the existence of this business. I think it is useless if we do run business but none knows the business. Communication is still important to spread the information to wider community (KRH)

No matter what the job is, in communication, students should be able to do presentation, discussion, and argumentation, not just making a conversation. These three skills are 
considered important in their future life whether they were going into a certain career or pursuing higher education. However, one student was really expressed surprising point of view. She expected that in teaching speaking, teachers should be able to integrate several teaching modes at a time: discussion, problem solving, and presentation.

\section{The students' preference of the speaking teachers}

Students at the FGD have a variety of point of views regarding to speaking teachers. Some of them preferred to have English native speakers in their speaking class. When they were asked further about their understanding of English native speakers, they did not really give uniform information. Some of them said that native speaker can be anyone as long as they did not speak Bahasa Indonesia,

$D$ : What do you mean by native speakers?

F: Their mother tongue is English or I mean as long as they are not Indonesian, they can be from Netherland, Rumania, Finland, China, Japan, etc.

Others said that native speaker is someone from English speaking countries such as United States, Australia, British, and New Zealand. Still others argued that as long as they were physically European people even though English was not their first language. The reason for having overseas teachers according to some students was since they cannot speak Bahasa. This is the key for imitation that the English should be like.

- When I cannot deliver my opinion in English, I will try my best in whatsoever I can to make him understand what I am saying. But if the lecturer is Indonesian, I will have a tendency to use Bahasa when they did not understand my opinion in English.

Other student at FGD expressed concerns about overseas teachers for not understanding the local students' cultures. These students suspected that the ELED chairman might only focus physical appearance as long as they are physically different from local students. According to the students, they did not even know what to teach in speaking subject. They were mostly confident only teaching material related to their background of knowledge. Students wanted the ELED chairman are more serious in selecting their speaking teachers especially those who were from overseas. The examples below are from students:

- In terms of the native teachers, I think the department should make an agreement with them. Because the case I found was when they taught students and students have the argumentation on a particular topic, they forced students to agree and say that you are wrong and I'm right. So it is impacted to students' skill of communication. Using that way, students did not really want to talk. After that case, students felt really afraid to give their opinion. The English Department should make agreement or to set teaching rules so this will not happen again. And native speakers did not use whatever they want to use in their teaching. They should know at least our cultures too.

- I had the experience when we were in speaking 2, my speaking teachers were from overseas. She taught us mostly something related to financial, management and it 
made me think that actually we did not need these materials. At first we never know what her academic background but when she frequently taught about ATM and piggy bank and some kinds of materials, we thought that she had management background. However, she did not know what she should teach us as the ED students.

Some students expressed that if the teachers are not from English speaking countries, the teachers should be really good at speaking and high critical thinking so that they can give good feedback. According to this student the communication competence matters much compare to the ethnicity.

However, with local teachers, students also expressed concerns. Teachers' capacity and delivery skills need to be securitized. Student at FGD argued that the speaking class was far from being interesting. Teachers focus more on the grammar. Thus, it frightened everyone since they are afraid of making mistakes while speaking. In addition, the topics given by the lecturer was not interesting either. They said that the speaking materials were similar to what they had learnt when they were in Senior High School. They need more challenging materials to improve the vocabulary and richen their English expression.

\section{The Students' Beliefs and Expectations}

Students also expressed belief that the catastrophic of students' undeveloped speaking skills was due to the leader's the lack of determination. Students claimed that they need leaders (managerial level personnel) are supposed to become a role model for everyone study at English Department at this target university. The leaders' determination personality helped to enforce students to speak and practice English not only in speaking class but also outside the class. Hence, this will create the English exposure and be able to lift the students up to the betterment of their communication level. In addition to that, the leaders' determination also plays crucial steps to reduce the teachers' denial attitudes. At FGD students expressed some teachers' irresponsible attitude such as coming very late for the class, too many absences for speaking class without prior notice so students felt that they got nothing in their speaking class. The ELED chairman was supposed to remind these teachers not just to let these things happened again and again.

- $\quad$ The first important thing we need is the effectiveness of teaching and process. Effective here is "no wasting time", but we can get more good results. But, up to now, I still don't get anything yet. What I mean here is, the lecturer should give us various materials, so that we can get more knowledge and improve our speaking skill. Sometimes, the lecturer only focus on one material for few meetings, that makes us really bored. The last important thing is the commitment of lecturer's attendance. My speaking lecturer has so many absences for this semester. She/he missed the class very often (NBL)

However, some students believed that the inadequacy of speaking skills were not merely due to teachers. Many students did not seem ready to accept challenges. They enrolled at the ELED for different reasons and their reasons determined their level of motivation. For example, some students are really genuine to improve their 
communication competence but some were not and being passive in the class. Therefore, they argued that perhaps, in addition to teaching skills, teachers should be able to create a class atmosphere where students' confidence will grow.

Students felt regretted as they have almost completed speaking subjects (Speaking 1, Speaking 2, Speaking 3, and Speaking 4), but they felt that their speaking skills did not improve significantly. As a matter of fact, several students claimed that the number of speaking classes set by the ELED did not really improve the speaking skill unless they also participate in English Day. They further described many students kept saying in Bahasa Indonesia during the English Day. There are some programs established by the ELED to facilitate students communicating not only when they were at classroom meetings. Those are English Day and Weekly Discussion.

The English Day is the two days- Monday and Wednesday- where all students must speak and communicate in English with both other students enrolled at English Department regardless their academic years and ELED teachers. All students at ELED were recommended to go to campus either for class schedule or just for socialization. Everyone are recommended to use the pin - "Speak English with me". It is as a reminder that English should be used elsewhere in the campus.

However, since at the Faculty of Education, there are also many students not only from ELED but also from other Departments- Biology, Mathematics, Indonesian, Civic Study, and Primary School Teachers-and many times they were mix especially outside the classroom meetings. this further complicated the supervision. When they were not obviously seen by the ELED teachers, they tended to speak Indonesian, except for very highly motivated students. So far, the ELED has not yet designed systematic ways to increase the number of participation from the students.

- I think more speaking classes (in the university) doesn't really help because language is habit. If you use it every day or continuously, you will get used to it. Although you have so many speaking classes, but you only use your English in the classroom, I think it will be useless. Let's think, how many hours you speak English in the class. Maybe, it less than one hour per meeting. Do you think that will help? I don't think so. We need to use it in our everyday life actually. Fortunately, we have English day in our department on Monday and Wednesday that force us to speak English outside the class. That's a good program actually. But, in reality it doesn't work. That's what makes me sad. We lacked of support from the department. Some students really try to speak whole English during English day, but not for the others. We do need support from the department to run this program well, so we can speak English each other more often.

- The department should have certain rules for the lecturers. The department also needs to pay attention on the surrounding, I mean to see whether the ELED students already speak English or not (related to English Day). We need to find out the systematic way to run the English Day. Maybe by giving punishment for those who don't speak English during English 
Day and reward for those who already speak whole English.

Even though students argued that to be able to speak English was their priority, they found some challenges in improving the communication level. The first most cited difficulties were to invite other students to speak English both in and outside the class due to the lack of determination and support from the ELED chairman and teachers. Besides, the selection of speaking teachers need urgent attention from ELED chairman especially their teaching qualification, delivery skill, pedagogical knowledge, and their communication skills.

A fundamental part of a need analysis entails the inclusion of learners' perspectives as a key component. This is because learners invest their time, money, and energy in learning knowledge and skills with the expectation that their investment will be useful. The expectations of students have been researched by many scholars (Evan and Green, 2007; Hyland, 1997; Leki and Carson, 1994). For example, Hyland (1997) surveyed 1619 students from eight disciplines at five Hong Kong tertiary institutions. Hyland's study revealed that students generally saw the value of English for Academic Purposes (EAP) classes as they recognize that proficiency in English is an important determinant of academic success in an English-medium learning environment. However, the students' perspectives on the need for language instruction varied according to their proficiency level, discipline and year of study. The findings indicated that less proficient students attached more importance to English classes than their more linguistically able counterparts that the subjects' language problems centered on the productive skills of writing and speaking, and, the acquisition of specialist vocabulary.

At a more specific skill level, numerous studies have examined different English language learning needs, for example, aural/oral communication needs (Ferris \&Tagg, 1996; Ferris, 1998). Others have examined writing needs (e.g., Casanave\& Hubbard, 1992; Jenkins, Jordan, Weiland, 1993; Afzali and Fakharzadeh, 2009; Huang, 2010). For instance, Huang (2010) reports on findings from a research project designed to assess undergraduate and graduate students' language-learning needs in the context of a new academic language support center at a Canadian university. A total of 432 students and 93 instructors of English as an Additional Language responded to questionnaires which asked them to rate the importance of academic writing. The findings indicated that there was much overlap in the skill items identified as being 'very important' by the graduate and undergraduate students and the instructors. However, students' self-assessments of their own writing skills and instructors' assessments of their students' writing skills differed dramatically. Even so, it is clear that learners have particular perspectives regarding their needs and these should be documented.

This study shows similarity to what Poedjiastutie and Oliver (2017) study thathad been conducted in the past two years. They states that it is apparent there are problems with communication. Upon graduation many students have achieved only minimal English proficiency.

\section{CONCLUSION}

This study clearly identified mismatches 
between the ED UMM curriculum and the students' learning needs. The findings from the stakeholders revealed several challenges at the program administration at the level of faculty, and the classroom.

There are three areas that both English Department and Faculty of Education should give more attention for the improvement of students' communication competence. The first is dealing with the speaking syllabuses. The goals of speaking subject should be made clear by having the students' voices heard and employing the appropriate Needs Analysis (NA) study. The second was the speaking teacher recruitment process should be made transparent. Either overseas or local teachers are supposed to follow the goals of teaching speaking, the teaching qualification and capacity that have been determined by the English Department. Last but not least is the importance for English Department to understand students' expectations of how speaking subjects should be run and implemented so that they will achieve communication development.

Students at UMM have pragmatic reasons for learning. They want to be able to communicate and master all the English language skills that will help them in their prospective careers, to gain overseas work and/or placement in international programs. They provided a number of suggestions of ways English teaching at UMM could be improved. Two of the main findings in this regard are improving the teaching capacity of staff at the institution and redefining several ELED and University policies related to pedagogy (e.g., smaller class size and streaming ESP classes based on proficiency). It is clear that to further enhance the students' success in English learning, some of the behaviours observed in the classrooms need to change.

Where English is a foreign language, as in Indonesia, it can be very difficult for language learners to find out opportunity to use it for communication because the society does not use it for daily interactions. Yet wider exposure to English would give students greater opportunities for using and, therefore, learning the target language. However, teachers can select particular groups or individuals who are committed English users and provide opportunities for students to meet with them. For example, this can be done by teachers inviting native speakers or expatriates who were living in locally to address their classes. Some exchange students from the ACICIS (Australian Consortium in Countries of Indonesian Study) program, Peace Corps, and exchange students from different parts of the world at UMM could also be invited to share their experiences and description of their cultures in English. Such activities could be conducted either regularly or as an incidental program. This would be particularly effective for speaking and listening classes as models of different English varieties could be provided by such classroom guests. In addition, teachers could invite some English school teachers, English courses instructors, parents who are able to speak English etc. to functions held for students at UMM. The more opportunities the teachers can create for students to hear English spoken and use their own English skills, the more confident students will become.

As revealed from both the FGDs, the majority students want English as a central part of the curriculum. However, many also demonstrated behaviour that suggested they were avoiding using it. This may occur as many students reported 
having negative English learning experiences during their high school years due to the focus on grammar teaching. Fortunately, there are many opportunities to engage with English at UMM. For example, the International Language Foundation is one of the English-speaking clubs for UMM students in which students have opportunities to use English for public speaking and debating. In addition, several units at UMM have their own English programs that students from any departments would be welcome to attend. For example, American Corner has a Movie Show program, conducted every month and often has guest lectures from the key persons from the USA discussing a variety of topics. However, these various opportunities need to be supported and promoted by the teachers and by UMM more generally.

\section{REFERENCES}

Afzali, K., \&Fakharzadeh, M. (2009). A needs analysis survey: The case of tourism letter writing in Iran. ESP World, 22(1). Retrieved from http:// www.esp-world.info/Articles_22/PDF/ $\mathrm{A} \% 20$ needs $\% 20$ analysis $\% 20$ survey. pdf

Brunton, M.W.C. (2009). An evaluation of students' attitudes to the general English and specific components of their course: a case study of hotel employees in Chiang Mai - Thailand. ESP World, Issue 4(25), Volume 8, 2009. Retrieved from http://www.espworld.info/Articles_25/ESP\% 20world\%20study.pdf

Casanave, C. P., \& Hubbard, P. (1992). The writing assignment and writing problems of doctoral students: Faculty perceptions, pedagogical issues, and need research. English for Specific Purposes, 11, 33-49.
Chen, Y. (2006). From the common core to specific. Asian ESP Journal, 1(3), Retrieved from http://www.asian-espjournal.com/June_2006_yc.php

Coleman, H. (2010). The English language in development. Retrieved from www.teachingenglish.org.uk/ transform/book

Crystal, D. (2003). English as a global language (2nd ed.). Cambridge: Cambridge University Press.

Erlandson, D.A., Harris, E.L., Skipper, B.L., \& Allen, S.D. (1993). Doing naturalistic inquiry: A guide to methods. Newbury Park, CA: Sage Publications.

Evans, S., \& Green, C. (2007). Why EAP is necessary: A survey of Hongkong tertiary students. Journal of English for Academic Purposes, 6, 3-17.

Ferris, D. (1998). Students' views of academic aural/oral skills: A comparative needs analysis. TESOL Quarterly, 32(2), 289-318.

Ferris, D., \&Tagg, T. (1996). Academic oral communication needs of EAP learners: What subject matter instructors actually require. TESOL Quarterly, 30(1), 31-58.

Finney, D. (2002). The ELT curriculum: A flexible model for a changing world. In J. C. Richard, \&Renandya, W.A. (Ed.), Methodology in language teaching: An anthology of current practice (pp. 69-79). Cambridge: Cambridge University Press.

Focho, G. N. (2010). Language as tool for global education: Bridging the gap between the traditional and global curriculum. Journal of Research in Innovative Teaching, 3(1), 135-148. Fraenkel, J. R., Wallen, N.E., \& Hyun, H.H. (2012). How to design and evaluate research in education (8th ed.). New York: Mc Graw-Hill. 
Ghenghes, P. (2013) Students and teachers of engineering speak out! What do you really need? AWEJ, 4 (1), $11-27$.

Hamp-Lyons, L. (2001). English for academic purposes. In R. Carter, \&Nunan, D. (Ed.), The Cambridge guide to teaching English to speakers of other languages (pp. 126-130). Cambridge: Cambridge University Press.

Huang, L. (2010). Seeing eye to eye? The academic writing needs of graduate and undergraduate students from students' and instructors' perspectives. Language Teaching Research, 14(4), 517-539. Retrieved from http:// ltr.sagepub.com website:

Huda, N. (2000). Kedudukan dan fungsi bahasa asing (The position and function of foreign languages). In $\mathrm{H}$. Alwi, \&Sugono, D. (Ed.), Politikbahasa: risalah seminar politikbahasa (Language politics: procedings of the seminar on language politics).(pp. 59-78). Jakarta: Pusat Bahasa dan Departemen Pendidikan Nasional.

Hyland, K. (1997). Is EAP necessary? A survey of Hong Kong undergraduates. Asian Journal of english Language Teaching, 7, 77-99.

Jenkins, J. (2003). World Englishes: A resource book for students. London and New York: Routledge English Language Introductions

Jenkins, S., Jordan, M.K.J., \& Weiland, P.O. (1993). The role of writing in graduate engeenering education: A survey of faculty beliefs and practices. English for Specific Purposes, 12, 51-67.

Kirubahar, J. S., Santhi, V.J., \&Subhashini, A. (2010). Personal and labour market environment factors in English for employability: A case study of KSA. Language in India, 10(4), 21-
29. Retrieved from www. language ini ndia.com website:

Kitkauskiene, L. (2006). General English and English for specifi c purpose. Santalka Filologija Edukologija, 14 (2), 88-92.

Lauder, A. (2008). The status and function of English in Indonesia: A review of key factors. Makara, Social Humaniora, 12(1), 9-20.

Leki, I. (2003). Research insights on second language writing instruction (Publication no. EDO-FL-03-06). Available from ERIC Clearing House on Language and Linguistics Washigton, DC

Leki, I., \& Carson, J.G. (1994). Students' perceptions of EAP writing instruction and writing needs across disciplines. TESOL Quarterly, 28(1), 67-79.

Lincoln, Y. \& Guba, E. (1985). Naturalistic Inquiry. Beverly Hills, CA: Sage.

McCawley, P. F. (2009). Methods for conducting an educational needs assessment: Guideliness for cooperative extention system professionals. Moscow: University of Idaho.

Netiksiene, N. (2006). Teaching English for specifi c purposes. Santalka Filologija Edukologija, 14(4), 80-82.

Oliver, R., Grote, E., Rochecouste, J., \&Exell, M. (2012). Addressing the language and literacy needs of aboriginal high school VET students who speak SAE as an additional language. The Australian Journal of Indigenous Education 41(2), 1-11.

Poedjiastutie, D. and Oliver,R. (2017). Exploring Students' Learning Needs: Expectation and Challenges. ELT Journal 10 (10), 124-133. DOI: https://doi.org/10.5539/elt. v10n $10 \mathrm{p} 124$ 